\title{
Retinal Dehydrogenase 1
}

National Cancer Institute

\section{Source}

National Cancer Institute. Retinal Dehydrogenase 1. NCI Thesaurus. Code C116058.

Retinal dehydrogenase 1 (501 aa, $\sim 55 \mathrm{kDa}$ ) is encoded by the human ALDH1A1 gene.

This protein is involved in the oxidation of retinaldehyde. 